\title{
Conception of "Peace through Health" in the "Middle East" Region: Report of the International Congress on Health for Peace, Shiraz, Iran
}

\author{
Hossein Molavi Vardanjani, $\mathrm{PhD}^{1}$; Alireza Salehi, MD, MPH, PhD ${ }^{2 *}$; Faramarz Aminlari, $\mathrm{MA}^{3}$ \\ ${ }^{1} \mathrm{MPH}$ Department, Shiraz University of Medical Sciences, Shiraz, Iran \\ ${ }^{2}$ Research Center for Traditional Medicine and History of Medicine, Shiraz University of Medical Sciences, Shiraz, Iran \\ ${ }^{3}$ Department of English Language, Shiraz University of Medical Sciences, Shiraz, Iran
}

\begin{abstract}
The discussions held by the congress panels can be boiled down to the following convictions. Health professionals, especially those who are working in the Middle East region, have to promote peace as part of their professional responsibility. Moving towards this objective can be realized through a number of measures. It is both necessary and feasible to increase research to identify the causes and consequences of war and violence; and to appropriately translate the findings to politicians, health professionals and masses of people. These can be achieved by means of boosting cooperation between international organizations and of bolstering the position of non-governmental organizations (NGOs) on a global scale. Showing respect to other societies and civilizations, encouraging cultural interactions between societies, and elevating public intellectuality and general demand for reduction of violence can be effective in decreasing the latter and the effects thereof. Of the engagements that health professionals must seriously take on is employing health diplomacy and curbing the accumulation of unrestricted power and unilateralism through enforcing international treaties. Finally, it is essential to make health systems more resilient to complex emergencies caused by wars so that they can survive such conditions.

Keywords: Armed Conflicts, Health, Iran, Middle East, Peace

Cite this article as: Molavi Vardanjani H, Salehi A, Aminlari F. Conception of "peace through health" in the "Middle East" region: report of the International Congress on Health for Peace, Shiraz, Iran. Arch Iran Med. 2020;23(4 suppl 1):S54-S59. doi: 10.34172/ aim.2020.s12.
\end{abstract}

Received: July 14, 2019, Accepted: October 12, 2019, ePublished: April 1, 2020

$\mathrm{V}$ iolence remains at the top of the list of threats to man's health. With the advent of extremist groups in our time and the metamorphosis of traditional wars into modern ones, health and security of the human societies around the globe, especially of civilians, is endangered like never before. ${ }^{1,2}$ This makes it an indispensable and urgent global necessity to take multilateral measures to curtail violence and promote health.

In an invaluable effort, the concept of "Health as Bridge for Peace" was proposed and recognized in the 1988 WHO's general assembly with the objective of making and building peace. ${ }^{3}$ According to this initiative, health professionals were to act based on scientific evidence and in several trajectories to promote peace. Multiple effective efforts followed, some of which are still in progress. A review of and scrutiny into the present standing of such efforts to recognize their weak and strong points, as well as the potential opportunities and threats they might face along the way, can go a long way to consolidate them.

Shiraz University of Medical Sciences and the Research and Technology Deputy of the Ministry of Health, jointly held the International Congress on Health for Peace in Shiraz, Iran, from November 13 to 16, 2018 (http:// healthpeace.sums.ac.ir/en). The congress had as objective expanding the dialogue on health for peace, and reviewing and evaluating the roles and duties of health professionals to reduce violence. The rate of breadth of participation was quite remarkable. University scholars, health professionals and representatives of health-related and non-governmental organizations (NGOs) from all across the globe welcomed the event. These included

- World Health Organization (WHO), country representative

- The United Nations International Children's Emergency Fund (UNICEF), country representative

- The United Nations Educational, Scientific and Cultural Organization (UNESCO), Tehran cluster office

- United Nations Population Fund (UNFPA), country representative

- International Committee of the Red Cross (ICRC), country representative

- International Physicians for the Prevention of Nuclear 


\section{War (IPPNW)}

- International Campaign to Abolish Nuclear Weapons (ICAN)

- Maastricht University, Netherlands

- Tampere University, Finland

- Yale University, US

- University of Waterloo, CA

- Several Iranian universities and NGOs

- Over 100 health professionals from Iran, Germany, India, Finland, Sweden, Netherlands, the US, Canada and England

More outstanding, however, was the achievement made by the congress in terms of being able to draw the attention from a myriad of various organizations, both governmental and non-governmental, from within the country, including

- Iran's Ministry of Foreign Affairs

- Iran's Presidential Department of Women and Families' Affairs

- Iran's 'Physicians with Social Responsibilities' (PSR)

- Collaboration and Strategic Planning Deputy of Iran's Ministry of Health

- Education Deputy of Iran's Ministry of Health

- The Department of International Ties of Iran's Ministry of Health

- Tehran Peace Museum

- Janbazan Medical and Engineering Research Center

- Tehran's Shahid Beheshti University

- Tehran University

- Iran University of Medical Sciences

- Tehran University of Medical Sciences

- Shiraz University

The ideas and research reports they brought to the congress branched out into nine panels. These are presented in Table 1, followed by a quick account of what the presentations and discussions in every panel boiled down to.

\section{International Cooperation and Development of Dialogue on Peace through Health}

According to the discussions held by the panelists, since the principle of "health for all" is a precursor to peace, which in turn is a prerequisite to "health for all", striving to achieve either one can have a crucial role in obtaining the other. At the same time, the nature of modern wars entails complicated conditions - a fact that calls for doubling of efforts by impartial organizations to preserve human rights. The WHO has to advocate and work towards gaining recognition of peace as an indispensable part of human rights and global sustainable development; the UNESCO has to develop the culture of peace in different societies and build trust in them; the UNICEF has to organize and run initiatives to minimize harms to children under the conditions of war and violence; and the ICRC has to provide health services and conduct rescue operations in critical war and post-war circumstances. The leading roles these organizations have to play in making such contributions must receive recognition and support from governments and NGOs and, as a result, from the global community.

Also needed is international cooperation to enable nations and governments to better handle war-induced complex emergencies. Efforts to make healthcare systems more resilient is an area of fundamental importance in international peace-promoting cooperation, as they can reduce harms done by wars and violence. Presenting healthcare services to refugees of wars in the receiving countries can also go a long way to ease down their pains. International cooperation must work to revive post-war societies, and to maintain peace and build trust. An important role in strengthening international collaborations can be played by medical journals, as they should publish on a constant basis the results of research on prevention and control of wars and on promoting peace.

\section{Epidemiology and Development of Dialogue on Peace through Health}

On this panel, definition of peace epidemiology, scope of the field, possible research designs over different phases of war and violence as well as the data at hand on the issue, and the challenges facing the field came under discussion. The result was a general consensus that, for a variety of reasons, the data on the effects of war and violence are insufficient and/or not quite reliable, and those on macro and micro causes of wars and on effective interventions are scarce.

As part of healthcare systems, epidemiologists hold the professional responsibility to ensure the validity of health information, and to identify the causes and risk factors of health-related events. Consequently, it is on epidemiologists to design and carry out studies, especially within an interdisciplinary framework, to address the gaps of information alluded to above.

Due to methodological limitations in this area, extra effort must go to development of methods to assure quality and precision of the data produced by studies. The translation of the knowledge gained from epidemiologic research to become usable by politicians as well as the public will substantially increase the success rate of efforts to prevent wars and decrease the risk of consequences thereof. Equally essential is that the novel and growing field of peace epidemiology thrive and be appropriately taught to health professionals and students for the sake of running interdisciplinary studies.

\section{Mental Health and Development of Dialogue on Peace through Health \\ Wars and violence break out as a result of unilateral decisions made by those in power. One way of thwarting}


Table 1. List of Panels and Speechmakers

\begin{tabular}{|c|c|c|c|}
\hline & Panel & Speechmaker & Topics of the Lectures \\
\hline & \multirow{7}{*}{$\begin{array}{l}\text { International Cooperation } \\
\text { and Development of } \\
\text { Dialogue on Peace } \\
\text { through Health }\end{array}$} & Reza Malekzadeh & International Scientific Cooperation, A Model for Peace-building through Health \\
\hline & & Mohammad Assai & $\begin{array}{l}\text { Health System Resilience as "the Capacity of Health Actors, Institutions, and Populations" to } \\
\text { Prepare for an Effective Response to Crises }\end{array}$ \\
\hline & & Christoph Hamelmann & The WHO's 'Health as a Bridge for Peace' \\
\hline 1 & & Will Parks & UNICEF's Global Interventions on Health for Peace: Examples from the Field \\
\hline 1 & & Soudabeh Ahmadzadeh & $\begin{array}{l}\text { Access to SRH and Maternal Health Services to Afghan Refugees Support Building Resilience } \\
\text { Capacities of Afghan Young Women }\end{array}$ \\
\hline & & Alexander Leicht & UNESCO's Global Interventions to develop Dialogue on Peace through Health \\
\hline & & Marc Achermann & $\begin{array}{l}\text { Caring for People Affected by Armed Conflicts: The Perspective of the ICRC on How Health } \\
\text { Can Contribute to Building Trust and Peace }\end{array}$ \\
\hline \multirow{5}{*}{2} & \multirow{5}{*}{$\begin{array}{l}\text { Epidemiology and } \\
\text { Development of Dialogue } \\
\text { on Peace through Health }\end{array}$} & Mohsen Rezaeian & Epidemiology and Peace through Health \\
\hline & & Hossein Molavi & Challenges of Epidemiological Research in Cases of Crisis and War \\
\hline & & AliAkbar Haghdoost & The Scope of Using War Epidemiology in Developing of Dialogue on Peace \\
\hline & & Reza Majdzadeh & Burden of Conflict and War in the Region of Middle East \\
\hline & & Kaveh Khoshnoud & Teaching a Course on Violent Conflict and Health \\
\hline \multirow{5}{*}{3} & \multirow{5}{*}{$\begin{array}{l}\text { Mental Health and } \\
\text { Development of Dialogue } \\
\text { on Peace through Health }\end{array}$} & Ali Firouzabadi & The Past Victim, the Future Abuser \\
\hline & & Amir Hossein Jalali & In Memorial of War Destructions, be Hopeful for Peace \\
\hline & & Morteza Nokhostin & The Future of Mental Health in the Non-Peace Era \\
\hline & & Babak Shamshiri & Psychological Approaches for Prevention of Violent Behaviors in Children \\
\hline & & Mohammad Taghi Yasamy & Psychosocial Mediators of War and Peace \\
\hline \multirow{6}{*}{4} & \multirow{6}{*}{$\begin{array}{l}\text { NGOs and Development } \\
\text { of Dialogue on Peace } \\
\text { through Health }\end{array}$} & Gunnar Westberg & $\begin{array}{l}\text { "Networking of NGOs for Peace through Health" and "The Effects of War and Conflicts on } \\
\text { Health }\end{array}$ \\
\hline & & Leila Moein & The Role of Women in Promotion of Health for Peace \\
\hline & & Arun Mitra & The Role of IPPNW in Health for peace \\
\hline & & Katja Goebbels & Working in Complex Situations - What Could Guide you? The Do No Harm Concept \\
\hline & & Aino Ritva Weyers & Humanitarian Consequences of Nuclear Weapons \\
\hline & & Shakeel Ur Rahaman & The Role of IPPNW in Health for Peace \\
\hline \multirow{5}{*}{5} & \multirow{5}{*}{$\begin{array}{l}\text { Health Systems and } \\
\text { Development of Dialogue } \\
\text { on Peace through Health }\end{array}$} & Mohsen Bayati & $\begin{array}{l}\text { Can Health be affected by Interpersonal Violence? A Panel Data Analysis on Countries in the } \\
\text { Middle East }\end{array}$ \\
\hline & & Reza Majdzadeh & Effect of Sanctions on People \\
\hline & & Amir Hosein Takian & Peace, Sustainable Health Development and the Place of Government \\
\hline & & Sajad Delavari & Health Diplomacy and its Place in Peace-building \\
\hline & & Remco Van de Pas & Health professionals and their Role as a Bridge for Peace \\
\hline \multirow{5}{*}{6} & \multirow{5}{*}{$\begin{array}{l}\text { Effects of War on health: } \\
\text { Case study of Imposed } \\
\text { war on Iran }\end{array}$} & Hossein Molavi & Scoping Review on the Effects of Imposed War on Iranians \\
\hline & & Naser Emadi & Health Status of Iranians Exposed to Chemical Weapons in Sardasht \\
\hline & & Batool Mousavi & Psychiatric Disorders in War Survivors and its Impact on their Partners \\
\hline & & Ali Khaji & A Review of the Health Related Articles of the Iraq-Iran War \\
\hline & & Zohreh Ganjparvar & Human Cost of the Imposed Iran-Iraq War \\
\hline \multirow{5}{*}{7} & \multirow{5}{*}{$\begin{array}{l}\text { Complex Emergencies } \\
\text { in Cases of War, and } \\
\text { Development of Dialogue } \\
\text { on Peace through Health }\end{array}$} & Pir Hossein Kolivand & Nature of Complex Emergencies in Cases of War \\
\hline & & Mohammad Javad Moradian & The Basics of Complex Emergencies \\
\hline & & Ahmad Soltani & The Role of Red Crescent Societies in Complex Emergencies \\
\hline & & Hesam Seyedin & Special Challenges of Complex Emergencies in Providing Healthcare Services \\
\hline & & Paul Bouvier & Health Care in Times of Crisis and Danger \\
\hline \multirow{8}{*}{8} & \multirow{8}{*}{$\begin{array}{l}\text { Human Rights, Medical } \\
\text { Ethics and Development } \\
\text { of Dialogue on Peace } \\
\text { through Health }\end{array}$} & Lotf Allah Dejkam & Right to Health and Just Health Care: Foundation of Peace \\
\hline & & Mostafa Mohaghegh-damad & Peace in the Islamic Ideology \\
\hline & & Mohammad Jafar Mahallati & $\begin{array}{l}\text { Global Loneliness and the State of Human Mental Health: How Can Religion Promote } \\
\text { Friendship as a Paradigm of Peace in Post-Modernity? }\end{array}$ \\
\hline & & Paul Bouvier & Providing Care to the Wounded and Vulnerable: a Core Duty of Humanity \\
\hline & & Rahim Nobahar & Holiness of Human Life: the Common Base for Health and Peace \\
\hline & & Saeed Rahimian & $\begin{array}{l}\text { The Relationship between Mysticism, Peace and Mental Health on Personal and Social } \\
\text { Dimensions }\end{array}$ \\
\hline & & Ehsan Shamsi Gooshki & $\begin{array}{l}\text { The Ebola Crisis: Emergence of "Cosmopolitan Solidarity" as a New Principle in Global } \\
\text { Health Ethics }\end{array}$ \\
\hline & & Mohammad Yusuf Nayeri & Peace and Health in Islamic Persian Culture \\
\hline \multirow{5}{*}{9} & \multirow{5}{*}{$\begin{array}{l}\text { Medical Education and } \\
\text { Development of Dialogue } \\
\text { on Peace through Health }\end{array}$} & Anneli Milén & Professional Education of Health: A Great Opportunity for Dialogue on Peace through Health \\
\hline & & Neil Arya & Medical Education and Health for Peace \\
\hline & & Mesbah Shams & Exploring Medical Peace Education and a Call for Peace Medicine \\
\hline & & Mohammad Bagher Khosravi & Curricular Intervention in Peace Education \\
\hline & & Mitra Amini & \\
\hline
\end{tabular}


such decisions is stifling the accumulation of unrestricted power. Another preventive measure would be leaving a positive effect on politicians in terms of making a change in the outlook they have of global governance. As this demands knowledge of one's past experiences, experts in psychology and psychiatry are likely to be capable of playing an effective role to this end.

At the same time, wars and violence have profound and long-lasting impacts on individuals mental and social health, of both combatants and civilians, and on the societies involved. The implication is that mental and social health experts need to analyze, out of their professional responsibility, the roots of wars and violence through sophisticated and multi-level models, and while employing cultural resources, design and implement interventions to curtail mental and social promoters and mediators that fuel wars and violence.

In spite of the presence of powerful external drivers such as financial goals to start and continue wars, the possibility is available of boosting internal peace, inter-personal peace, and peace between countries and between civilizations, all through enabling individuals and nations to cope with the experience of "being in-between". ${ }^{4}$ Elevating mental and social health can be attained through raising nations' intellectuality, achievable in turn by educating them, teaching them how to think critically, and showing them what the real picture of the consequences of wars and violence looks like.

\section{NGOs and Development of Dialogue on "Peace Through Health"}

The panel came to the unanimous conviction that since most wars and violence are initiated and sustained by governments, it would be on NGOs to play their part in preventing and curtailing them. The panelists believed that to augment NGOs' role in making and building sustainable peace, a number of measures, (similar to those already initiated, and being supported by IPPNW), can be taken. These include emphasizing peace through empowering individuals and societies to cope with warinduced complex conditions; promoting the enforcement of, and respect for, multilateral agreements among nations; preventing destructive and unilateral international rules from being passed; developing and heightening friendship among societies across the globe; pressuring arms manufacturers to reduce the production of massdestructive weapons; and trying to convince governments to decrease their military budgets.

The panelists believed that to operationalize and enforce such measures, once they start, NGOs must seek the support of economic powers as well as the cooperation of trained volunteers. The latter can educate the masses on the risk factors (including upstream ones) of wars as well as their consequences, as a means of strengthening public demand for the reduction of all forms of violence.
Along this path, positive interaction with politicians can be highly constructive.

The members of the panel also came to the conclusion that one of the areas of activity for NGOs would be to try to sensitize physicians to the macro causes of wars and health-related political issues. Providing medical students and physicians with education on peace through health, and collecting and publishing statistics on the destructive effects of wars on people's health can create in this group the intended sensitivity.

\section{Health Systems and Development of Dialogue on Peace through Health}

In addition to providing healthcare services, health systems hold other responsibilities such as training the work force and ensuring the required resources for the provision of health. Health systems must therefore plan for capacity building so as to ensure health over the long run.

The mutual relationship between peace and health, i.e. two major components of global sustainable development, demands that health systems make every effort to prevent wars and violence and to promote peace. Health systems' involvement in making and building peace can result in ensuring health both at present and in the future. They have the capacity, and the obligation, to contribute to sustaining peace and health through empowering, and efficiently employing, the potentialities of the global health diplomacy (GHD). ${ }^{5}$ Convincing governing bodies to provide the right grounds for making appropriate decisions with the objective of reducing wars and violence can be the invaluable result of the promotion of GHD.

Health systems would also need to make themselves resistant to, and ready for, war conditions and emergencies in order to govern health-related issues under such conditions. Health systems must plan for, and work toward the prevention of inter-personal violence.

\section{Effects of War on Health: Case Study of the War Imposed on Iran}

Wars have quite varied effects on the societies engaged, ranging from the destruction of infrastructures to harms to the mental health of combatants' family members, even many years after they end. Today, of the most important and probably the most vulnerable individuals affected by wars are the civilians. A case in point is the war imposed by Iraq on Iran, in which the former made frequent use of chemical weapons against Iranian civilians. The devastating effects have never ceased to have their grip on the victims, even after several decades following the termination of the war. Lack of respect at the time by Iraq for the health of another nation backed by its military superiority as well as the lengthening of the war led to a substantial increase in war-induced damages.

Nonetheless, few studies have been carried out to date on the effects of that war. It is essential, however, that 
research that provides evidence on the short-, mediumand long-term war-induced damages be conducted on a large scale. An increase in the provision of such evidence as well as presenting it in efficient ways to communities and their leaders across the planet can go a long way to decrease wars and acts of violence.

7. Complex Emergencies in Cases of War, and Development of Dialogue on Peace through Health Discussions that were held on this panel can be summarized in what follows. Wars normally lead to complex conditions under which the governments lose control over the elements affecting health and security. An inevitable consequence is extensive displacements of the surviving residents of the areas involved, a crisis with an aftermath that usually lasts for many years. These displacements impose an incredible burden on the health of the societies, which is even more massive than that caused by the devastation directly following the wars, e.g. casualties and loss of lives.

Health professionals need to strengthen their efforts and share them with international organizations. It is also essential that they are equipped with necessary skills and training to be able to provide basic healthcare as well as urgent medical services in the complex emergencies. Furthermore, they must make concentrated efforts to pave the way for a boost in the effectiveness of initiatives intended to reduce the complexity of emergency conditions, both during and after the war. Exchange of past experiences and orchestration of multilateral activities between and among relief organizations and governments are important considerations they need to invest in. Finally, health professionals can use their health services, during the time they are offering them, as a means of stopping or diminishing the severity of wars.

\section{Human Rights, Medical Ethics and Development of Dialogue on Peace through Health}

The panelists were convinced that since human rights and medical ethics constitute the main foundations of peace through health initiatives, it behooves the holders of different views on these two concepts to bring their paradigms together and edge their differences away through international cultural dialogues. Examples of principles shared by different viewpoints include belief in "justice" and in "equal civil rights", "avoidance of unilateralism", "commitment to provision of man's health" and "the sanctity of man's life".

Here are some suggestions made by this panel to promote peace through health initiatives: trying to avert the misuse of religion for attaching to people labels of blasphemy; working to construct plausible agencies to promote positive and truthful inter-personal and inter-societal interactions; portraying the consequences of previous wars and violence; initiating dialogues and materializing cultural assimilation of societies; boosting health equity on an international scale; and benefiting from cultural and religious lessons from different societies to promote peace and friendship.

\section{Medical Education and Development of Dialogue on Peace through Health}

Promoting peace and preventing violence requires resistance against the latter. The health workforce is the major body where such resistance can manifest itself. In their routine education, health professionals are not trained on how to promote peace or minimize the effects of war and violence, especially so in developing and lessdeveloped countries. At the same time, their professional responsibility requires that they have the capability to play a role in reducing armed and structural violence. To this end, being aware of the components and requirements of achieving peace in its every dimension can be effective and extremely useful. In fact, for many years now, education on peace through health has been in place in some highranking universities. Ironically, however, in developing and less-developed countries, which are more seriously involved in different forms of violence, such education is non-existent. Identifying models of education on peace, tailoring them to local needs, integrating them within medical education curricula or presenting them in the form of optional short- or long-term programs and employing efficient education methods to teach them are precursors to peace through health.

\section{Summary}

The discussions held by the congress panels can be boiled down to the following convictions. Health professionals, especially those who are working in the Middle East region, have to promote peace as part of their professional responsibility. Moving towards this objective can be realized through a number of measures. It is both necessary and feasible to increase research to identify the causes and consequences of war and violence; and to appropriately translate the findings to politicians, health professionals and masses of people. These can be achieved by means of boosting cooperation between international organizations and of bolstering the position of NGOs on a global scale. Showing respect to other societies and civilizations, encouraging cultural interactions between societies, and elevating public intellectuality and general demand for reduction of violence can be effective in decreasing the latter and the effects thereof. Of the engagements that health professionals must seriously take on is employing health diplomacy and curbing the accumulation of unrestricted power and unilateralism through enforcing international treaties. Finally, it is essential to make health systems more resilient to complex emergencies caused by wars so that they can survive such conditions. 


\section{Authors' Contribution}

All authors contributed equally to this manuscript.

\section{Conflict of Interest Disclosures}

There was no conflict of interest.

\section{Ethical Statement}

The International Congress on Health for Peace (ICHP) was approved by Shiraz University of Medical Sciences.

\section{Funding Sources}

There was no funding source.

\section{References}

1. Roberts A. The civilian in modern war. Yearbook of International Humanitarian Law. 2009;12:13-51. doi:10.1017/ S1389135909000026
2. Guha-Sapir D, Schlüter B, Rodriguez-Llanes JM, Lillywhite L, Hicks MH. Patterns of civilian and child deaths due to warrelated violence in Syria: a comparative analysis from the Violation Documentation Center dataset, 2011-16. Lancet Glob Health. 2018;6(1):e103-e110. doi: 10.1016/S2214109X(17)30469-2.

3. WHO. Health as Bridge for Peace (HBP). Available from: https://www.who.int/hac/techguidance/hbp/en/. Accessed March 2, 2019.

4. Franks A, Meteyard J. Liminality: the transforming grace of inbetween places. J Pastoral Care Counsel 2007;61(3):215-22. doi: 10.1177/154230500706100306.

5. Brown MD, Bergmann JN, Novotny TE, Mackey TK. Applied global health diplomacy: profile of health diplomats accredited to the UNITED STATES and foreign governments. Global Health. 2018;14(1):2. doi: 10.1186/s12992-017-0316-7. 